\title{
INTERRELATION MULTIFACTORS OF MICE DESTINATION TO TOURIST REVISIT
}

\author{
Ni Made Eka Mahadewi ${ }^{1}$, Komang Gde Bendesa ${ }^{2}$ and I Made Antara ${ }^{2}$ \\ ${ }^{1}$ Sekolah Tinggi Pariwisata Bali, Nusa Dua, Bali, Indonesia \\ ${ }^{2}$ Universitas Udayana, Denpasar, Bali, Indonesia
}

\begin{abstract}
This paper presents a study on the multi factors of MICE destination by explaining how the tourism system approach implemented in a role of tourism destinations and its affects to the MICE industry as sub sectors. The MICE destination is influenced by multi factors where defined as product of MICE destination, satisfaction, image, promotion and its effect to tourist revisit. The result of research shows that promotion contributes the biggest effect to Revisit, both directly as well as indirectly through image. It means that tourist visit to Bali for MICE destination can be enhanced through promotion.
\end{abstract}

Keywords- Tourism system approach; MICE; Multifactors; Promotion; Destination

\section{INTRODUCTION}

The tourist visit, in Indonesia, is expected to increase to be 9.2 million persons in 2014 from 8.6 million persons in 2013. The number of tourist visit in 2013 amounted to $8,637,275$ persons, or a growth of 7.37 percents compared to 2012 in which the number of visit was as many as 8.04 million persons. For domestic tourists in 2013, the number of trips reached 248 trips with an average expenditure on each trip reached $\mathrm{Rp} .711$ thousand. The number of meetings in the form of MICE tourism has become part of efforts to enhance tourist visit to Indonesia. Bali is one of the leading tourist destinations in the world. Bali is still the icon of Indonesian tourism up to the present. Bali is again crowned as the best tourist destination (Island Destination of the Year) in the event China Travel \& Meeting Industry Awards 2013. This award is regarded as one of the forms of recognition by the international community to Bali which has successfully managed tourism industry and MICE (meetings, incentives, conference and exhibition) in excellent world-class. MICE needs to be always developed, because: (1) MICE business market is a market that is not easily affected by fluctuations than leisure tourism [1]; (2) MICE Tourists are generally classified into 'quality tourists' who tend to stay longer and spend more money than regular travelers [2]; (3) MICE travelers spending is 7 times more than ordinary travelers [3]; (4) Related to the effects of globalization, the competition of MICE business has shifted from competition amongst firms becomes competition amongst destinations [4].

In relation to Bali as a MICE destination, within a period of 5 years from 2008-2012, it was recorded that MICE activities were only $7.63 \%$ in 2008 with a ratio of the number of tourists both foreign and domestic, and the number of tourists visiting Bali attending MICE activities was about $4.93 \%$ tourists in the year 2009, about $6.01 \%$ tourists in 2010. about $4.25 \%$ in 2011 and $7.30 \%$ in 2012 .

Received: April 12, 2019

Reviewed: June 20, 2019

Accepted: July 5, 2019

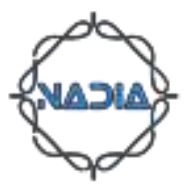


Therefore, this research reveals on how the multifactors effects of MICE destination attributes, promotions and satisfaction to visit back (revisit) through image.

The rest of this paper is organized as follow: Section 2 describes the proposed method. Section 3 presents the obtained results and following by analysis. Finally, Section 4 concludes this work.

\section{PROPOSED METHOD}

This research is one of the writing forms to determine the factors affecting tourist revisit to Bali. This study is composed using SEM (Structural Equation Modeling). The discussion of this research refers to the theory of Consumer Behavior, emphasizing on the factors of tourist decision-making and tourism systems approach particularly tourism planning. A complete SEM Modeling essentially consists of Measurement Model and Structural Model. Measurement is intended to confirm a dimension or factor based on the indicators. Structural model is a model on the structure of relationships forming or explaining causality amongst factors. As per the rules of SEM, this study applies the same thing, preparing a research model with the measures specified in the rules of SEM as follows.

\subsection{THEORETICAL MODEL FORM}

Theoretical Model Form is described in Table I below.

Table I. Theoretical Model

\begin{tabular}{|c|c|c|}
\hline Cons & ruct & Dimension \\
\hline \multicolumn{3}{|c|}{ 1. Exogenous Construct: } \\
\hline \multirow{7}{*}{\multicolumn{2}{|c|}{ a) Attribute MICE Destination }} & Bali as MICE Destination (X1.1) \\
\hline & & Meeting Facilities (X1.2) \\
\hline & & Hotel with MICE facilities (X1.3) \\
\hline & & Accessibilities (X1.4) \\
\hline & & Event with its entertainment (X1.5) \\
\hline & & Infrastructure (X1.6) \\
\hline & & Airport Facility (X1.7) \\
\hline \multirow{5}{*}{\multicolumn{2}{|c|}{ b) Promotion }} & Publication (X2.1) \\
\hline & & Incentive (X2.2) \\
\hline & & Friend/Relatives (X2.3) \\
\hline & & Word of Mouth (X2.4) \\
\hline & & Advertising \\
\hline \multirow[t]{5}{*}{ c) } & Satisfaction & Competitive Price (X3.1) \\
\hline & & Ground Handling (X3.2) \\
\hline & & Security Standard (X3.3) \\
\hline & & Food \& Beverage Standard (X3.4) \\
\hline & & e. Information services (X3.5) \\
\hline & MICE Planning & Plan to revisit Bali for MICE(X4) \\
\hline & MICE Policy & Policy for MICE Business (X5) \\
\hline \multicolumn{3}{|c|}{ 2. Endogenous Construct } \\
\hline \multirow{4}{*}{\multicolumn{2}{|c|}{ a. Image }} & Bali is safe (Y1.1) \\
\hline & & Bali is clean (Y1.2) \\
\hline & & Easy public transport (Y1.3) \\
\hline & & Professional staffs (Y1.4) \\
\hline \multirow{4}{*}{\multicolumn{2}{|c|}{ b. Revisit }} & $\begin{array}{l}\text { Frequently come to Bali for many times } \\
\text { (Y2.1) }\end{array}$ \\
\hline & & $\begin{array}{l}\text { b. Decide to choose Bali with your } \\
\text { friend/relatives (Y2.2) }\end{array}$ \\
\hline & & Opportunity revisit Bali in the future (Y2.3) \\
\hline & & $\begin{array}{l}\text { Will revisit Bali with your } \\
\text { family/friend/relative (Y2.4) }\end{array}$ \\
\hline
\end{tabular}


Adopted from Mc.Intosch in [5]; Scmoll in [6]; Parasuraman, et al., [7]; Mill and Morrison in [8]; Getz in [9]; Cooper et.al, in [10]; Oppermann and Chan,in [11]; Swarbrooke and Horner in [12]; Buhalis in [13]; Gunn in [13]; Leiper in [14]; Goldblatt in [15]; Jago et.al, in [16]; Weaver and Lawton in [17]; Schiffman and Kanuk in [18]; Berridge in [19]; Wagen in [20]; Hall in [21]; Holloway et.al, in [22]; Kottler in [23], [24].

\subsection{TOURISM SYSTEM APPROACH MODEL}

The MICE tourism businesses in tourism is part of artificial attraction (manmade attraction). The venue of holding MICE as the selected destination is part of the research. Figure Conceptual Framework is a research model with tourism approach. The conceptual framework of the research model is an abstraction and synthesis of theories and research problems. This research refers to the concepts and theories which are aimed to determine the effect of MICE destination attributes, promotion and satisfaction to image and revisit of MICE travelers to Bali. This model is expected to be able to answer the problems revealed previously. Figure 1 below illustrates an overview of the research to be conducted with the approach of writing research, conceptual framework and research model.

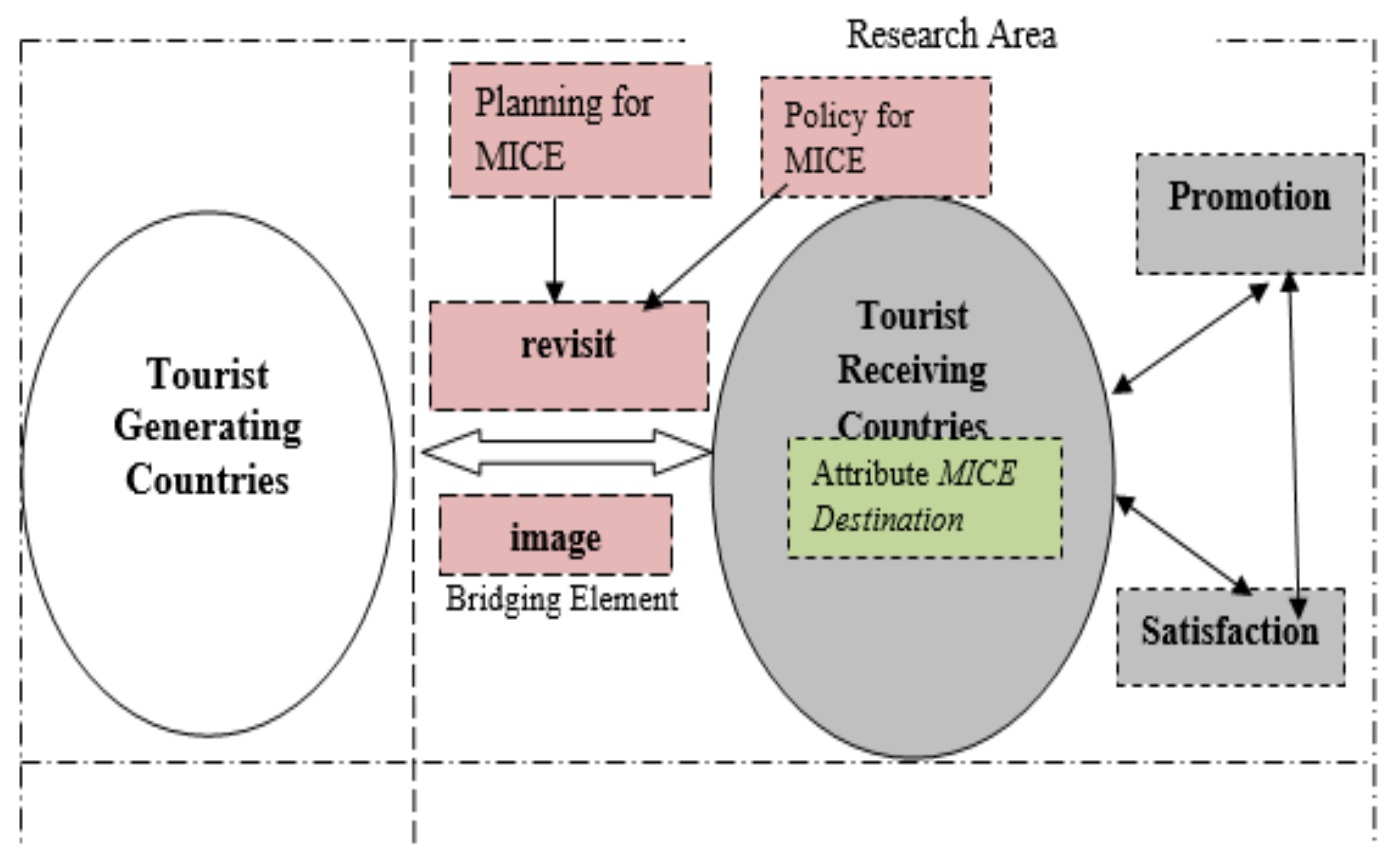

Fig. 1 Tourism System Approach - Research Model

Adopted from Mc.Intosch in [5]; Scmoll in [6]; Parasuraman, et al., [7]; Mill and Morrison in [8]; Getz in [9]; Cooper et.al, in [10]; Oppermann and Chan,in [11]; Swarbrooke and Horner in [12]; Buhalis in [13]; Gunn in [13]; Leiper in [14]; Goldblatt in [15]; Jago et.al, in [16]; Weaver and Lawton in [17]; Schiffman and Kanuk in [18]; Berridge in [19]; Wagen in [20]; Hall in [21]; Holloway et.al, in [22]; Kottler in [23], [24]. Referring to Bali as one of the leading tourist destinations in the world, Bali is still a national tourism icon until now. With various unique cultural attractions plus the nature, which is still beautiful, and the service provided, Bali can attract tourists to visit. The activities of MICE in Bali, within the last ten years have increased in term of the number of participants. The MICE activities in Bali are dominated by events Meetings and Conference. For Incentive and Exhibition activity has not increased in term of activities. 


\section{RESULTS AND DISCUSSION}

The research was conducted in three (3) largest venues in Bali. In this study, respondents used are MICE participants. The questionnaires were distributed at two meeting venues, namely at the Bali International Convention Center (BICC) and Grand Hyatt Hotel Nusa Dua. 189 questionnaires were collected. The biggest number of respondents came from Asian countries about 84 persons (44.4\%); the countries in American territories about 39 persons (20.6\%); Australian countries about 57 persons $(30.2 \%)$; European countries about 9 persons $(4.8 \%)$. For the age of respondents who were pleased to participate in this research ranged $41-50$ year about $50.8 \%$. For the age of older than 50 years occupied the second position with the number of 86 persons or about $45.5 \%$, and the age category of 30-40 years was about 7 persons or $3.7 \%$. The description of respondents is illustrated in Table II below.

Table II. Respondent Description

\begin{tabular}{|c|c|c|c|c|}
\hline No. & Classification & Criteria & Total & $\%$ \\
\hline \multirow[t]{4}{*}{1.} & Group Country & a. Asia & 84 & 44,4 \\
\hline & & b. Australia & 57 & 30.2 \\
\hline & & c. America & 39 & 20.6 \\
\hline & & d.Europe & 9 & 4,8 \\
\hline \multirow[t]{3}{*}{2} & Age & a. $30-40$ years & 7 & 3,7 \\
\hline & & b. 41-50 years & 96 & 50.8 \\
\hline & & c. $>50$ years & 86 & 45,5 \\
\hline \multirow[t]{3}{*}{3.} & Job & a. Government & 48 & 25,4 \\
\hline & & b. Business & 89 & 47,1 \\
\hline & & c. Professional & 48 & 25,4 \\
\hline \multirow[t]{3}{*}{4.} & Length of Stay & a. 1-3 days & 7 & 3,7 \\
\hline & & b. 4-6 days & 112 & 59,3 \\
\hline & & c. 7-9 days & 70 & 37,0 \\
\hline \multirow[t]{3}{*}{5.} & Expenditure & a. < USD 1000 & 7 & 3,7 \\
\hline & & b. USD 1000-3000 & 125 & 66,1 \\
\hline & & c. > USD 3000 & 57 & 30.2 \\
\hline
\end{tabular}

The variables observed in this research include 5 latent variables (unobservable variables), namely MICE Destination (X1), promotion (X2), convention tourist satisfaction (X3), image (Y1) and decision making to visit back/revisit (Y2), and 2 (two observable variable), namely, the plan to visit Bali for MICE purpose (X4), and MICE business policy (X5). The details of composite variable descriptions are as follows:

\subsection{MICE DESTINATION (X1)}

Latent exogenous variables of MICE Destination (X1) consists of 7 indicators, namely Bali as a MICE Destination (X1.1), meeting facilities (x1.2), hotels with all their facilities (X1.3), accessibility (X1.4), Event with its entertainment (X1.5), Infrastructure (X1.6), Airport Facilities (X1.7). The respondents' assessment of the indicators and latent exogenous variables of MICE Destinations (X1) is in the average of 4.29 and the standard deviation of 0.851 means that overall respondents providing responses tended to agree to the indicator statements of the MICE Destination variable (X1).

\subsection{PROMOTION (X2)}

Latent exogenous variables of Promotion (X2) consist of 5 indicators, namely Publications (X2.1), Incentive (X2.2), Friends/ relationships (X2.3), word of mouth (X2.4), Advertising (X2.5). The respondents' assessment of the indicators and latent exogenous variables of Promotions (X2) is in the average of 3.55 and the standard deviation of 0.819 means that overall respondents providing responses tended to agree to the indicator statements of Promotion variable (X2). 


\subsection{CONVENTION TOURIST SATISFACTION (X3)}

Latent exogenous variables of convention tourist satisfaction (X3) consists of 4 indicators, namely competitive shop price (X3.1), ground handles (X3.2), consistent security officer (X3.3), standard food and beverage (X3. 4). The respondents' assessment of the indicators and the latent exogenous variable of convention tourist satisfaction (X3) is in the average of 3.79 and the standard deviation of 0.857 means that overall respondents providing responses tended to agree to the indicator statements of convention tourist satisfaction variable (X3).

\subsection{IMAGE (Y1)}

Latent endogenous of Image variable (Y1) consist of four indicators, namely, Bali is safe as destination (Y1.1), Cleanliness of destinations (Y1.2), Public transport/taxi (Y1.3), workforce are professionals in their field (Y1.4). The respondents' assessment of the indicators and the latent exogenous variables of Image (Y1) is in the average of 3.81 and the standard deviation of 0.708 means that overall respondents providing responses tended to agree to the indicator statements of Image variable (Y1).

\subsection{REVISIT (Y2)}

Latent endogenous variables of Revisit (Y2) consist of 4 indicators, namely, frequent visits (Y2.1), prefer friends/relations (Y2.2), opportunity to visit in the future (Y2.3), will visit with relatives/friends/relations (Y2.4). The respondents' assessment of the indicators and the latent endogenous variable of Revisit (Y2) is in the average of 3,12 and the standard deviation of 0.901 means that overall respondents providing response tended to quiet agree to the statements of the indicator of Revisit variable (Y2).

\subsection{PLAN TO VISIT BALI FOR MICE (X4) AND MICE BUSINESS POLICY (X5)}

Observable exogenous variables in this research include plans to visit Bali for MICE destination (X4) and MICE business policies (X5). The respondents' assessment of the observable exogenous variables of plan to visit Bali for MICE destination (X4) is in the average of 4.67 and the standard deviation of 1.046 means that overall respondents providing responses tended to agree to the statements of Plan to visit Bali for MICE (X4). While the average value of the MICE business policy (X5) is in the average of 4.38 and the standard deviation of 1.043 means that overall respondents giving responses tended to agree on the statements of MICE business policy (X5). Validity in every factor are tested. The result of test by using Confirmatory Factor Analysis shows that the value of loading factor at the seven indicators on X1 is significant. All loading values are higher than 0.5 and significant $(p<\alpha)$, then all indicators can be applied to measure the Attribute of MICE Destination (X1), namely, X1.1 -X1.7. The result of test of X2 shows that the four loading values are higher than 0.5 and significant $(\mathrm{p}<\alpha)$, and one indicator on word of mouth (X2.4) provided loading value of less than 0.5 although it is significant, so there are four indicators can be applied to measure Promotion (X2), namely, Publication (X2.1), Incentive (X2.2), Friends/relations (X2.3), and Advertising (X2.5). Latent endogenous convention tourist satisfaction (X3) consists of 5 indicators; the five loading values are greater than 0.5 and significant $(\mathrm{p}<\alpha)$, therefore all the indicators can be used to measure convention tourist satisfaction (X3). The result of test latent endogenous of Image variables (Y1) shows that all indicators can be used to measure the Image (Y1). The result of revisit test (Y2) shows that the values of loading factors on the three indicators of loading factor are greater than 0.5 and significant $(\mathrm{p}<\alpha)$, and there is an indicator of opportunity to visit in the future (Y2.3) contributing loading value of less than 0.5 despite significant, then all indicators can be used to measure Revisit (Y2). 
Reliability in every factor calculated. The calculation of reliability in this research applied composite (construct) reliability with a minimum cut-off value of 0.7 . The result shows that all indicators are reliable. After all validity and reliability tests were conducted in each latent variable, some prerequisite to be complied in structural modeling are the assumption of normal multivariate, the assumption of no multicollinearity or singularity and outlier.

\section{a. NORMALITY TEST}

The complete results on normality test of the data in all research variables reveals a Pearson Correlation value between $\mathrm{dj}$ and $\mathrm{q}$ of 0.942 or $\mathrm{p}=0.000<\alpha=0.05$ level, or the number of data at 68.7831 which is more than 50 percents, so that it can be said that the data distribute normal multivariate.

\section{b. SINGULARITY TEST}

The results of research provide Determinant of the sample covariance matrix value of 0.0000001 . This value is almost close to zeros; thus, it can be said that there is a singularity problem in the data being analyzed, but the value of the AMOS program may still produce parameter coefficient.

\section{c. MULTICOLINEARITY}

The results of research can be said to have no multicolenearity problems in the data being analyzed, since mostly there is no relationship occurring amongst variables.

\section{d. OUTLIER}

There are three outlier data in this research, however as it is still below 5 percents of the observations, they can be said that no outlier happens.

a. Having tested the validity and reliability of all latent variables of which results are valid and reliable, the data are not normal multivariate, no multicollinearity and outlier occur below 5 percents, then the latent variables can be continued in the analysis in the form of a path diagram presented as follows. We look for the effects of MICE Destination (X1), promotion (X2), convention tourist satisfaction (X3), Bali as MICE Destination (X4), and MICE Business Policy (X5) to the decision-making to revisit (Y2) through image (Y1). 


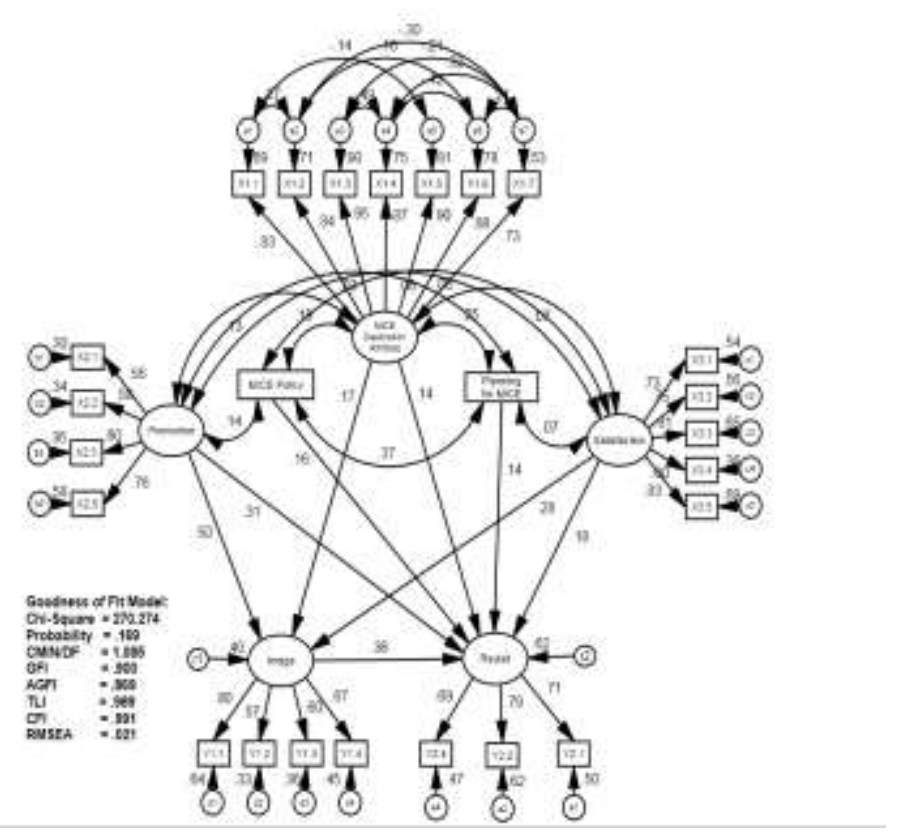

Fig. 2 Attribute of MICE Destination (X1), Promotion (X2), MICE Tourist Satisfaction (X3), Planning for MICE Destination (X4), and MICE Business Policy (X5) to decisionmaking to revisit (Y2) through image (Y1)

The test results of the above complete model by the application of AMOS program can be completely seen in the following Table III.

Table III. The Result of Test for Decision Making Model to Revisit (Y2) through Image (Y1)

\begin{tabular}{lccc}
\hline Criteria & Cut-Off Value & $\begin{array}{c}\text { Result of } \\
\text { Calculation }\end{array}$ & Remarks \\
\hline Chi - Square & $\begin{array}{c}\text { Expected to be } \\
\text { small }\end{array}$ & 269,690 & $\begin{array}{c}\chi^{2} \text { with df }=424 \\
\text { is } \begin{array}{l}473,009 \\
\text { Good }\end{array}\end{array}$ \\
\hline $\begin{array}{l}\text { Significance } \\
\text { Probability }\end{array}$ & $\geq 0.05$ & 0.124 & Good \\
\hline RMSEA & $\leq 0.08$ & 0.024 & Good \\
\hline GFI & $\geq 0.90$ & 0.900 & Good \\
\hline AGFI & $\geq 0.90$ & 0.866 & Quite Good \\
\hline CMIN/DF & $\leq 2,00$ & 1,105 & Good \\
\hline TLI & $\geq 0.90$ & 0.987 & Good \\
\hline CFI & $\geq 0.90$ & 0.989 & Good \\
\hline
\end{tabular}

The Table III above shows that 8 (eight) criteria used to assess the worth/not of a model reveals the remarks of Good and Quite Good. It can be said that the model is acceptable, meaning that there is compliance between the model and data. Of the compliance model, each path coefficient can be interpreted. The coefficients of this path are hypothesized in this research, which can be presented in the following structural equation:

$$
\begin{gathered}
\mathrm{Y} 1=0.151 \mathrm{X} 1+0.505 \mathrm{X} 2+0.282 \mathrm{X} 3 \\
\mathrm{Y} 2=0.147 \mathrm{X} 1+0.312 \mathrm{X} 2+0.180 \mathrm{X} 3+0.142 \mathrm{X} 4+0.165 \mathrm{X} 5+0.366 \mathrm{Y} 1
\end{gathered}
$$


Where,

$\mathrm{X} 1=$ Attribute of MICE Destination

$\mathrm{X} 2=$ Promotion

X3 = MICE Tourist Satisfaction

X4 = Planning for MICE Destination

X5 $=$ MICE Business Policy

$\mathrm{Y} 1=$ Image

$\mathrm{Y} 2=$ Decision-Making to Revisit

Path coefisient test in Figure 2 above and the equations above are presented in detail in the following Table IV:

Table IV. The Result of Test on Model Compliance pf Decision-Making to Revisit (Y2)

\begin{tabular}{lcccc}
\hline Variable & Coefisient & C.R. & Prob. & Remarks \\
\hline MICE Destination (X1) $\rightarrow$ image (Y1) & 0.151 & 2.073 & 0.038 & Significant \\
\hline Promotion (X2) $\rightarrow$ image (Y1) & 0.505 & 4.802 & 0.000 & Significant \\
\hline $\begin{array}{l}\text { Convention tourist satisfaction (X3) } \rightarrow \\
\text { image (Y1) }\end{array}$ & 0.282 & 3.491 & 0.000 & Significant \\
\hline $\begin{array}{l}\text { MICE Destination (X1) } \rightarrow \text { Decision- } \\
\text { Making to Revisit (Y2) }\end{array}$ & 0.147 & 2.181 & 0.029 & Significant \\
\hline $\begin{array}{l}\text { Promotion (X2) } \rightarrow \text { Decision-Making to } \\
\text { Revisit (Y2) }\end{array}$ & 0.312 & 2.949 & 0.003 & Significant \\
\hline $\begin{array}{l}\text { Convention Tourist Satisfaction (X3) } \rightarrow \\
\text { Decision-Making to Revisit (Y2) }\end{array}$ & 0.180 & 2.362 & 0.018 & Significant \\
\hline $\begin{array}{l}\text { Plan to Visit Bali for MICE (X4) } \rightarrow \\
\text { Decision-Making to revisit (Y2) }\end{array}$ & 0.142 & 2.051 & 0.040 & Significant \\
\hline $\begin{array}{l}\text { MICE Business Policy (X5) } \rightarrow \\
\text { Decision-Making to revisit (Y2) }\end{array}$ & 0.165 & 2.377 & 0.017 & Significant \\
\hline $\begin{array}{l}\text { image (Y1) } \rightarrow \text { decision-making to } \\
\text { revisit (Y2) }\end{array}$ & 0.366 & 3.348 & 0.000 & Significant \\
\hline
\end{tabular}

Based on Table IV above, the interpretation to each path coeficient are as follows:

- Attributes of MICE Destinations (X1) has a positive effect and significant on the image (Y1). It can be seen from the path coefficient with positive sign in the value of 0.151 with CR of 2,073 and significance probability (p) of 0.038 which is smaller than significant level $(\alpha)$ which has been set at 0.05 . Thus, MICE Destinations (X1) directly affect the image (Y1) of 0.151 , meaning that every increase in MICE Destinations (X1) will raise the image (Y1) of 0.151 .

- Promotion (X2) has a positive effect and significant on the image (Y1). It can be seen from the path coefficient with positive sign in the value of 0.505 with CR of 4.802 and significance probability (p) of 0.000 which is smaller than significant level $(\alpha)$ which has been set at 0.05 . Thus, promotion (X2) directly affects the image (Y1) of 0.505 , meaning that every increase in promotion $(\mathrm{X} 2)$ will raise the image $(\mathrm{Y} 1)$ of 0.505 .

- MICE tourist satisfaction (X3) has a positive effect and significant on the image (Y1). It can be seen from the path coefficient with positive sign in the value of 0.282 with CR of 3,491 and significance probability (p) of 0.000 which is smaller than significant level $(\alpha)$ which has been set at 0.05 . Thus, the convention tourist satisfaction (X3) directly affects the image (Y1) of 0.282 , meaning that every increase in convention tourist satisfaction (X3) will raise the image (Y1) of 0.282.

- Attributes of MICE Destinations (X1) has a positive effect and significant on decision making to return/revisit (Y2). It can be seen from the path coefficient with positive sign in the value of 0.147 with CR of 2,181 and significance probability (p) of 0.029 which is smaller than significant level $(\alpha)$ which has been set at 0.05 . Thus, MICE 
Destinations (X1) directly affects the decision-making to visit back/revisit (Y2) of 0.147 , meaning that every increase in MICE Destinations (X1) will raise the return/revisit (Y2) of 0.147 .

- Promotion (X2) has a positive effect and significant on decision making to return/revisit (Y2). It can be seen from the path coefficient with positive sign in the value of 0.312 with a value of CR of 2.949 and significance probability (p) of 0.003 which is smaller than significant level $(\alpha)$ which has been set at 0.05 . Thus, promotion (X2) directly affects the decision-making to visit back/ revisit (Y2) of 0312, meaning that every increase in MICE Destinations (X) will raise the return/revisit (Y2) of 0.312 .

- MICE tourist satisfaction (X3) has a positive effect and significant on decision making to return/revisit (Y2). It can be seen from the path coefficient with positive sign in the value of 0.180 with a value of CR of 2,362 and significance probability (p) of 0.018 which is smaller than significant level $(\alpha)$ which has been set at 0.05 . Thus, the convention tourist satisfaction (X3) directly affects the decision-making to visit back/revisit (Y2) of 0.180 . Hence, it means that every increase in convention tourist satisfaction (X3) will raise the return/revisit (Y2) of 0.180 .

- MICE Planning or plan to visit Bali for MICE destination (X4) has a positive effect and significant on decision making to return/revisit (Y2). It can be seen from the path coefficient with positive sign in the value of 0.142 with a value of $\mathrm{CR}$ of 2,051 and significance probability (p) of 0.040 which is smaller than significant level $(\alpha)$ which has been set at 0.05 . Thus, plan to visit Bali for MICE destination (X4) directly affects the decision making to return/revisit (Y2) of 0.142 , meaning that every increase in plan to visit Bali for MICE destination (X4) then will raise the return/revisit (Y2) of 0.142 .

- MICE business policy (X5) has a positive effect and significant on decision making to return/revisit (Y2). It can be seen from the path coefficient with positive sign in the value of 0.165 with a value of $C R$ of 2.377 and significance probability (p) of 0.017 which is smaller than significant level $(\alpha)$ which has been set at 0.05 . Thus, MICE business policy (X5) directly affects the decision-making to return/ revisit (Y2) of 0.165 meaning that every increase in MICE business policy (X5) will raise the return/revisit (Y2) of 0.165 .

- Image (Y1) has a positive effect and significant on decision making to return/revisit (Y2). It can be seen from the path coefficient with positive sign in the value of 0.366 with a value of CR of 3.348 and significance probability (p) of 0.000 which is smaller than significant level $(\alpha)$ which has been set at 0.05 . Thus, image (Y1) directly affects the decision-making to return/revisit (Y2) of 0.366, meaning that an increase in each image (Y1) will raise the return/revisit (Y2) of 0.366.

Direct relationship occurs between latent exogenous variables (Attributes of MICE Destinations (X1), Promotion (X2), MICE Tourist Satisfaction (X3) and Plan to Visit Bali for MICE Destination (X4), MICE Business Policy (X5), with latent endogenous intervening variables (Image (Y1)) and latent endogenous variables (decision making to return/revisit (Y2)). The following Table $\mathrm{V}$ presents the direct result of direct relationship occurs amongst the variables - latent exogenous and endogenous variables: 
Table V. Direct Effect of Research Variables

\begin{tabular}{clcc}
\hline \multirow{2}{*}{ Direct Effect } & & \multicolumn{1}{c}{$\begin{array}{c}\text { Variabel } \\
\text { Intervening }\end{array}$} & $\begin{array}{c}\text { Variabel } \\
\text { Endogen }\end{array}$ \\
\cline { 3 - 4 } & & Image (Y1) & $\begin{array}{c}\text { Decision-Making to } \\
\text { return/revisit (Y2) }\end{array}$ \\
\hline \multirow{5}{*}{$\begin{array}{c}\text { Exogenous } \\
\text { Variabels }\end{array}$} & $\begin{array}{l}\text { Attribute of MICE } \\
\text { Destination (X1) }\end{array}$ & 0.151 & 0.147 \\
\cline { 2 - 4 } & Promotion (X2) & 0.505 & 0.312 \\
\cline { 2 - 4 } & $\begin{array}{l}\text { MICE Tourist } \\
\text { Satisfaction (X3) }\end{array}$ & 0.282 & 0.180 \\
\cline { 2 - 4 } & $\begin{array}{l}\text { Plan to Visit Bali for } \\
\text { MICE (X4) }\end{array}$ & 0.000 & 0.142 \\
\cline { 2 - 4 } & $\begin{array}{l}\text { MICE Business } \\
\text { Policy (X5) }\end{array}$ & 0.000 & 0.165 \\
\hline Intervening & Image (Y1) & 0.000 & 0.366 \\
\hline
\end{tabular}

From the Table $\mathrm{V}$ above, it can be described that the direct effects of latent exogenous variables to latent endogenous variabels is high. $\mathrm{X} 2$ provides the highest direct effect to $\mathrm{Y} 1$, then $\mathrm{Y} 1$ to $\mathrm{Y} 2$ and $\mathrm{X} 2$ to $\mathrm{Y} 1$. Indirect relationship occurs between latent exogenous variables (Attributes of MICE Destinations (X1), Promotion (X2), MICE Tourist Satisfaction (X3) and Plan to Visit Bali for MICE Destination (X4), MICE Business Policy (X5), with latent endogenous intervening variables (Image (Y1)) and latent endogenous variables (decision making to return/revisit (Y2)). The following Table VI presents the indirect result of indirect relationship occurs amongst the variables - latent exogenous and endogenous variables:

Table VI. Indirect Effect of Research Variables

\begin{tabular}{clcc}
\hline \multirow{2}{*}{ Direct Effect } & & \multicolumn{1}{c}{$\begin{array}{c}\text { Variabel } \\
\text { Intervening }\end{array}$} & $\begin{array}{c}\text { Variabel } \\
\text { Endogen }\end{array}$ \\
\cline { 2 - 4 } & & Image (Y1) & $\begin{array}{c}\text { Decision-Making to } \\
\text { return/revisit (Y2) }\end{array}$ \\
\hline \multirow{5}{*}{$\begin{array}{c}\text { Exogenous } \\
\text { Variables }\end{array}$} & $\begin{array}{l}\text { Attribute of MICE } \\
\text { Destination (X1) }\end{array}$ & 0.000 & 0.055 \\
\cline { 2 - 4 } & $\begin{array}{l}\text { Promotion (X2) } \\
\text { MICE Tourist }\end{array}$ & 0.000 & 0.185 \\
\cline { 2 - 4 } & $\begin{array}{l}\text { Satisfaction (X3) } \\
\text { Plan to Visit Bali for }\end{array}$ & 0.000 & 0.103 \\
\cline { 2 - 4 } & $\begin{array}{l}\text { MICE (X4) } \\
\text { MICE Business }\end{array}$ & 0.000 & 0.000 \\
\hline Policy (X5) & 0.000 & 0.000 \\
\hline Intervening & Image (Y1) & 0.000 & 0.000 \\
\hline
\end{tabular}

From the Table VI above, it can be described that the indirect effects of latent exogenous variables to latent endogenous variabels is high. Y1 provides the highest indirect effect on $\mathrm{X} 2$ to $\mathrm{Y} 2$, then on $\mathrm{X} 3$ to $\mathrm{Y} 2$. Total effect constitutes the sum of direct and indirect effect between latent exogenous variables (Attributes of MICE Destinations (X1), Promotion (X2), MICE Tourist Satisfaction (X3) and Plan to Visit Bali for MICE Destination (X4), MICE Business Policy (X5), with latent endogenous intervening variables (Image (Y1)) and latent endogenous variables (decision making to return/revisit (Y2)). The following Table VII presents total result on the direct and indirect result of relationship occurring amongst the variables - latent exogenous and endogenous variables: 
Table VII. Total Effect of Research Variable

\begin{tabular}{clcc}
\hline \multirow{2}{*}{ Direct Effect } & & \multicolumn{1}{c}{$\begin{array}{c}\text { Variabel } \\
\text { Intervening }\end{array}$} & $\begin{array}{c}\text { Variabel } \\
\text { Endogen }\end{array}$ \\
\cline { 2 - 4 } & & Image (Y1) & $\begin{array}{c}\text { Decision-Making to } \\
\text { return/revisit (Y2) }\end{array}$ \\
\hline \multirow{5}{*}{$\begin{array}{c}\text { Exogenous } \\
\text { Variables }\end{array}$} & $\begin{array}{l}\text { Attribute of MICE } \\
\text { Destination (X1) }\end{array}$ & 0.151 & 0.203 \\
\cline { 2 - 4 } & $\begin{array}{l}\text { Promotion (X2) } \\
\text { MICE Tourist } \\
\text { Satisfaction (X3) }\end{array}$ & 0.505 & 0.496 \\
\cline { 2 - 4 } & $\begin{array}{l}\text { Plan to Visit Bali for } \\
\text { MICE (X4) }\end{array}$ & 0.282 & 0.283 \\
\cline { 2 - 4 } & $\begin{array}{l}\text { MICE Business Policy } \\
\text { (X5) }\end{array}$ & 0.000 & 0.142 \\
\hline Intervening & Image (Y1) & 0.000 & 0.165 \\
\hline
\end{tabular}

From the Table VII above, it can be described that the total effects of latent exogenous variables to latent endogenous variabels is high. X2 provides the highest total effect to $\mathrm{Y} 1$, then $\mathrm{X} 2$ to $\mathrm{Y} 2$ and $\mathrm{Y} 1$ to $\mathrm{Y} 2$.

\section{CONCLUSSION}

Overall, tourists are interested in Bali for leisure purposes. This is shown by the data of tourist arrivals to Bali which are dominated by leisure travelers. MICE tourists coming to Bali are continuously afforded to be able to revisit. Bali has prepared services, facilities and infrastructure. Various other attempts have been made to increase tourist visits Bali for MICE, namely by continuing to do promotion, service and good image. The result of research shows that promotion contributes the biggest effect to Revisit, both directly as well as indirectly through image. It means that tourist visit to Bali for MICE destination can be enhanced through promotion.

\section{REFERENCES}

[1] Zhang, Hanqin Qiu, Vivien Leung, and Hailin Qu, "A refined model of factors affecting convention participation decision-making", Tourism Management, 28.4, (2007): 1123-1127.

[2] Bailey, James E. "Toward a science of metabolic engineering", Science, 252.5013, (1991): 1668-1675.

[3] Messner, W., \& Schäfer, N., "The ICCA facilitator's manual: intercultural communication and collaboration appraisal", GloBus Research Limited, (2012).

[4] Govers, R. "Destination image evaluation: Part II", Eclipse: The Periodic Publication from Moonshine Travel Marketing for Destination Marketers, 10.1, (2003): 1-12.

[5] McIntosh, Robert P., "Forests of the Catskill Mountains, New York", Ecological Monographs, 42.2, (1972): 143-161.

[6] Schmoll, Gottfried A., "Tourism Promotion: marketing background, promotion techniques and promotion planning methods", Tourism International Press, (1977).

[7] Parasuraman, Anantharanthan, Valarie A. Zeithaml, and Leonard L. Berry, "A conceptual model of service quality and its implications for future research", Journal of marketing, 49.4, (1985): 41-50.

[8] Mill, Robert C., and Alastair M. Morrison, "The Tourism System, Englewood Cliff", N. J. Prentice Hall, (1985).

[9] Getz, Donald, "Event tourism: Definition, evolution, and research", Tourism management, 29.3, (2008): 403-428.

[10] Vojtek, Anne B., Stanley M. Hollenberg, and Jonathan A. Cooper, "Mammalian Ras interacts directly with the serine/threonine kinase Raf", Cell, 74.1, (1993): 205-214.

[11] Chan, Paul K., Mary C. Oppermann, and Shie-Shin Wu, "North Carolina's experience in development of pavement performance prediction and modeling", Transportation research record, 1592.1, (1997): 8088.

[12] Buhalis, Dimitrios, "Marketing the competitive destination of the future", Tourism management, 21.1 (2000): 97-116.

[13] Gunn, Clare A., and Turgut Var, “Tourism planning: Basics, concepts, cases”, Psychology Press, (2002).

[14] Leiper, Neil, “Tourism management”, Frenchs Forest: Pearson Education Australia, Vol. 455, (2004).

[15] Goldblatt, David, "Knowledge and the social sciences: theory, method, practice”, Routledge, (2004). 
[16] Jago, Leo K., and Margaret Deery, "Relationships and factors influencing convention decision-making", Journal of Convention \& Event Tourism, Taylor \& Francis Group, Vol. 7. No. 1, (2005).

[17] Weaver, David Bruce, and Laura Jane Lawton. "'Just because it's gone doesn't mean it isn't there anymore': Planning for attraction residuality", Tourism Management, 28.1, (2007): 108-117.

[18] Schiffman, Susan S., "Taste and smell losses in normal aging and disease", Jama, 278.16, (1997): 13571362.

[19] Berridge, Kent C., "The debate over dopamine's role in reward: the case for incentive salience", Psychopharmacology, 191.3, (2007): 391-431.

[20] Obama, Barack, and Hoffnung Wagen, "Gedanken zur Rückbesinnung auf den American Dream", München: Riemann, (2007).

[21] Hall, Colin Michael, Tourism planning: Policies, processes and relationships", Pearson Education, (2008).

[22] Holloway, C., C. Humphreys, and R. Davidson, "The business of tourism. Essex", (2009).

[23] Kottler, Joan R, "Yoga pants with padded knees", U.S. Patent Application No. 12/382,024.

[24] Suryani, Anne, "Comparing case study and ethnography as qualitative research approaches", (2013). 